\title{
Sabhara Kudus Police Unit Effort In Combating Adulterated Liquor In Kudus District
}

\author{
Deni Dwi Noviandi ${ }^{1}$ and Aryani Witasari ${ }^{2}$
}

Abstract. The issues of law enforcement in combating adulterated liquor in the Kudus Police Region, There are two (2) ways circulation of liquor law enforcement carried out by the Sabhara Kudus Police unit, namely preventive and repressive. As for preventive measures carried out where possible and still their awareness to obey the law. While repressive action is action taken if preventive measures are not effective, so that the people carrying out the law though involuntarily. While the police in law enforcement there are (two) action that is persuasive and repressive action which has its own purpose.

Constraints faced by the Sabhara Kudus Police Unit in combating adulterated liquois related to the limited number of Members of the unit Sabhara Police at the sanctuary that is generally still not satisfactory, not maximum, and uneven steps socialization PERDA (Regional Regulation) conducted at the societal level, so far not uncommon understanding less precise with regard to the procedures or systems at the time of preparation until the determination of regulation efforts Sabhara Police Unit in combating Kudus adulterated liquor in the Kudus Police Region. Effort or attempt Sabhara Police Unit of the Kudus in minimizing the violation is by way of non-judicial and pro justicia. Non-judicial action is accomplished by providing guidance, exhort or guide in order not to repeat the mistakes that have been made that violates local laws. If this action is less provide a deterrent effect and the parties related to underestimate, then the action pro justicia, the actions of pro justicia is taken when actions coaching or non judicial considered insufficient because only given guidance only, then Sabhara Kudus Police Unit may soon crack down and will be brought to trial and be subjected to probation.

Keywords: Sabhara Kudus Police Unit ; Adulterated liquor.

\section{Introduction}

Most people who consume alcohol have made the activities of drinking alcohol as a habit that is difficult to overcome. Consuming alcohol include the elderly, young, teenagers, and even children have started to try to drink it because of curiosity as well as environmental factors. Alcoholic beverages are now becoming one of the issues that are significant in Indonesia. Many victims as a result of this drink. This drink is often used as a beverage for custom events, or as a drink to have fun because this drink does cause addictive effects. Alcohol, if consumed in excess, can cause disease. ${ }^{3}$

\footnotetext{
${ }^{1}$ Student of Master of Law, Universitas Islam Sultan Agung Semarang and Members of the Indonesian National Police (Polri), email: bbony77@yahoo.com

${ }^{2}$ Faculty of Law, Universitas Islam Sultan Agung

${ }^{3}$ Hartati, Nurwijaya, 2009, Bahaya Alkohol dan Cara Mencegah Kecanduannya. PT. Elex Media Kompitindo. Jakarta p. 1.
} 
Seller liquors circulate unofficially still a lot so that the police do not hesitate to raid and seize even penalize sellers of liquor that does not have that permission. Judging from the high number of liquor obtained from the police raid operation proves that the Kudus District still very vulnerable circulation of liquor. The impact of the liquor is quite dangerous to society. Not to mention if the liquor has been started to be consumed by children who are not old enough as a result of the association in the neighborhood. The child could only imitate the behavior of their parents or relatives or the environment around his home that resulted in the child to do so. ${ }^{4}$

The Ministry of Commerce has tried to prevent the circulation of liquor in mini market or supermarket or other public places through the Trade Minister Regulation No. 6 of 2015 on Control and Supervision of Procurement, Distribution and Sale of Alcoholic Beverages. This new rule is a revision of Decree No. 20 / M-DAG / PER / 4/2014 on the Control and Supervision of Procurement, Distribution and Sale of Alcoholic Beverages. One of the things that set is related to the banning of minimarket and retailers to sell alcoholic beverages with alcohol content below 5\% or types of beer. In Article 14 of the Regulation No. 20/2014 states that the retailers can sell beer is composed of minimarket, supermarkets, hypermarkets and other retailers. With the new Permendag, then there is a revision to eliminate minimarket and other retailers that minimarket and retailers can not sell beer. Other retailers include stalls which covers 12 square meters. ${ }^{5}$

Based on the problems described above, the authors are interested in doing research with the title "Sabhara Unit Effort In Combating Adulterated Liquor Of The Kudus Police In Kudus District". Based on the title of the problem can be formulated as follows: 1) How can law enforcement in combating adulterated liquor in territory of Kudus Police? 2) What is the limiting factor in law enforcement in combating adulterated liquors in the territory of Kudus Police? 3) How are Sabhara Kudus Police Unit in combating adulterated liquor in the Kudus Police District?

\section{Discussion}

\subsection{Law Enforcement In Combating Adulterated Liquor In Territory Of Kudus Police}

Implementation of the law according to the enforcement of regulation number 12 of 2004 on the prohibition of circulation of alcoholic beverages in Kudus district. Assisted by the Regent supervisory and control teams as referred to in Article 3. In law enforcement have increased raids and surveillance against illegal circulation of alcoholic beverages, but the operating business is expected to remain a consistent

\footnotetext{
${ }^{4}$ Soerjono Soekanto, 1990, Sosiologi Suatu Pengantar, PT. Raja Grafindo Persada, Jakarta, p. 494.

${ }^{5}$ http://finance.detik.com/read/2015/01/28/202639/2817027/4/ini-rincian-aturan-larangan-bir- sold-inminimarket Accessed on 23 Septeember 2018 At 16:49 pm
} 
To provide a deterrent effect for the dealer or seller who acted fraudulently or through the trading illegally and sell hard drinking Adulterated. This effort is a business Sabhara Kudus Police Unit in minimizing the occurrence of crime. For traffickers or illegal sellers who commits an offense, Sabhara Kudus Police Unit crack down immediately and not just the members of the administrative sanctions only, but immediately closed the business because it saw the previous experience of the vendor underestimated because only sanctioned only. ${ }^{6}$

In conducting the necessary law enforcement cooperation and coordination in order to Kudus Police forces capability and the Kudus district government further strengthened to increase the evenness, smoothness, efficiency, coherence and effectiveness in the implementation of tasks in controlling the sale of adulterated liquoplace the action indicated irregularities. Visible Results Sabhara interview with AKP Sutopo, SH.:

'Ranks of Sabhara Kudus Police Unit general duty on the course of enforcing the local rules, forms of enforcement of the regulations in particular areas of the oversight conducted Sabhara Kudus Police Unit against illegal sale of alcoholic beverages and adulterated liquor. ${ }^{7}$

Law enforcement in the form of supervision, internal and external supervision, guidance on places of illegal sale of alcoholic beverages, and demolition of places of illegal sale of alcoholic beverages. internal control such as conducting raids carried around in a scheduled and non-scheduled. External supervision in the form of reports from the public about the existence of places of committing criminal offenses adulterated liquor circulation disturbing public order, and then followed up appropriate internal control procedures by conducting raids at the scene. Normal supervision, namely: ${ }^{8}$

- Oversight does not find fault, that does not find fault who is wrong, but also find ways to improve

- Supervision is a continuation of a process running continuously so as to obtain the results of surveillance are interlinked

- Supervision should ensure the possibility of taking quick and appropriate correction to prevent errors.

- Supervision is education which educate that can be stimulating to improve and regulate the condition of the object of supervision.

According to the KBO of Sabhara Kudus Police law enforcement area, enforcing is the task of the unit. Its implementation in the form of surgery is usually done 3 weeks or according to public complaints and by an assignment letter from the Chief of Police. "During these operations it carried out in places that are prone to be leluasanya

\footnotetext{
${ }^{6}$ Interview with Head of Sabhara Kudus Police Unit, AKP Sutopo, SH

${ }^{7}$ lbid.

${ }^{8}$ Ibid.
} 
circulation of alcohol. The main focus is dimly lit stalls where the Kudus district had become rampant and indicated to the practice of prostitution, as well as places that are likely to carry more of a combined circulation of liquor that have previously been the target of the operation." 9

In the implementation of the Sabhara Kudus Police Unit refers dikelurkan warrant by the Chief of Police in order to avoid imbalance of power, which in operation it holds the letter as the basis for robust operation. Each warrant operation is always changing. Operating results no less adulterated liquor seized as evidence. Illegal liquor of any variety that does not have a clearance, and the wine, putihan or Adulterated who created their own society. This proves that the Sabhara Kudus Police Unit not just do a raid operation, it is always unyielding combat unscrupulous rogue sellers who distribute adulterated liquor is, no doubt in the action it clashed with business owners who do not want to place in check. There was little evidence seized in the operating results. Evidence will be recorded and will be destroyed before all the parties concerned and the joint operations conducted in the Kudus district state prosecutors, usually held on the occasion commemorating the International Narcotics Day (HANI). ${ }^{10}$

\subsection{Which Is A Barrier To Do Law Enforcement In Combating Adulterated Liquor in Kudus Police Territory}

A number of obstacles that hinder efforts to improve the performance and improvement of the Sabhara Kudus Police Unit like:

- In connection with the limited number of officers of the Sabhara Kudus Police Unit generally still not satisfactory. Compared with the tasks to be carried out in accordance task, not only the number of officers are far from adequate compared to the magnitude of the problems encountered in the field.

- One factor contributing to the lack of effective implementation of the legislation at the community level is not maximized and the uneven pace of socialization PERDA conducted at the societal level, so it is still quite a lot of people who have not gained an understanding optimal in the process of internalization of values or rules contained in by law.

- So far it is not uncommon their lack of understanding of exactly related to the procedure or the system at the time of preparation until the determination of the decision, so often seen the emergence of a situation of inconsistency in which the level of implementation or application of the rules is considered beneficial and are dominated by the interests of the institution / certain institutions, while harming agencies / institutions in the public eye.

\footnotetext{
${ }^{9}$ Interview with KBO of Sabhara Kudus Police Unit, Mr. Deni

${ }^{10}$ Kudus Police, Adj interview Sabhara Mr. AKP Sutopo., SH
} 
- Another serious problem faced by the Sabhara Kudus Police Unit in enforcing the legislation and create tranquility and order in society are limited facilities and infrastructure available.

- In many ways not the least of the Sabhara Kudus Police Unit members felt that the limited budget allocations given by Police turned out to provide a significant effect on their performance.

- So far it is felt that the fight against adulterated liquors and attempts to create tranquility and public order is plagued by problems of coordination between relevant agencies are not established and runs optimally.

- The issue of the actual combat Adulterated liquor can also be examined by the public. That is the problem eradicate adulterated liquor, the creation of peace and order can not be separated from economic and socio-cultural konsisi politics developed within the community. Low levels of education, lack of access of citizens to information resources of significant limitations of economic conditions, lack of understanding and interpretation of existing regulations, the emergence of the interests of a particular political, habit or cultural values developed in the community are some of the many factors that can contribute to the effectiveness of combating adulterated liquor done.

- In terms of implementation eradicate adulterated liquor that often arises is the limited onggota Sabhara itself, where in combating adulterated liquor considered not regulate the issue of sanctions or the threat of an adequate.

Outside the principal obstacles mentioned above, it is possible there are other factors that hamper efforts to improve the performance of the Sabhara Kudus Police Unit in law enforcement criminal offense of alcohol. However, in the spirit of revitalizing and strong ideals, undoubtedly many of these challenges will be overcome, especially when there is genuine support from the community as a whole and the role of the balance of all relevant government agencies.

Not only the Sabhara Kudus Police Unit but also the police are also experiencing problems experienced as an investigator in conducting criminal investigations liquor circulation happens, is as follows:

- internal factors; In carrying out the investigation on the crime of liquor one such constraints is the problem of infrastructure Satresnarkoba Kudus Police in tackling the crime of trafficking of liquor due to the lack of laboratory criminals who facilitate the investigation, because this place is useful as a means to prove with the naked eye between drinks the original hard or fake. Lack of socialization conducted by the police.

- external factor; This factor is of a society, of public awareness is relatively low which affects the smoothness in investigating criminal offenses circulation of alcohol, lack of awareness of the consequences of alcohol. Alcohol as a part of 
daily life, even this difficulty has been experienced for a long time. This habit is considered a disease of society where often conducted raids are still doing the same thing. This suggests traders are not committing a crime deterrent circulation of alcohol, because the benefits are also great as well as the penalty of only more than 1 year (misdemeanor) if the violation of article 2 regulation no. 8 in 2008.

Generally people is key to the success of law enforcement officials that the Police in law enforcement criminal offense liquor. Thus the need for cooperation between the respective parties. Because often it carried out the raid but has spread out into the community.

From these discussions actually arise why such enforcement is no constraint on the theory of the passage of the law as a law enforcement function in society divided into three kinds of things the rule of law as a rule. About the enactment of the rule of law there is a presumption as follows. ${ }^{11}$

- The rule of law applies legally, based on the rule of law which is higher (Hans Kelsen), or when it is formed according to a predetermined manner (W. Zevenbergen) if it shows the relationship between a state requirement and consequently (JHA Logemann)

- The rule of law applies in sociological, if this rule will be effective if the rules enforceable by the authorities, although not accepted by the community (theory of power), or earlier rules apply as accepted and recognized by the community (recognition theory)

- The legal maxim applies philosophically, in accordance with the ideals of positive law as the highest value.

\subsection{Sabhara Kudus Police Unit Effort In Combating Adulterated Liquor In Kudus District}

The execution was carried out through the operations performed at $09.30 \mathrm{pm}$ and according to public complaints and according to its own initiative Sabhara Unit. In relation to the complaints from the public, the Sabhara Kudus Police Unit ascertain in advance by asking members whether the reported location or place it really is no circulation of alcohol or not. After that, if reported correctly place it is a place to store, sell, or manufacture of alcohol, the Sabhara Kudus Police Unit direct raid. "During this time it carried out the operation in the places vulnerable the circulation of alcohol, mosalnya gardens are now widely used for young kids hanging out, and the dimly lit stalls to stalls selling herbs. ${ }^{12}$

\footnotetext{
${ }^{11}$ Soerdjono Soekanto,1993, Penegakan Hukum, Binacipta, p. 29

${ }^{12}$ Interview with AKP Sutopo., SH, op.cit.
} 
Operating results were a bit of alcohol were seized as evidence. This proves that the Sabhara Kudus Police Unit really doing his duty and prove that the Sabhara Kudus Police Unit not just do a raid operation, it is always unyielding combat rogue sellers. In the action of the Sabhara Kudus Police Unit clashed with the owner of the goods in this case alcoholic beverages that do not want the place inspected. The seized evidence will be recorded and will be destroyed before all parties concerned and carried out in the town square Kudus District, bisaanya implemented in time after the rally to celebrate the students.

\section{Closing}

\subsection{Conclusions}

- There are two (2) ways circulation of liquor law enforcement carried out by the Sabhara Kudus Police Unit, namely preventive and repressive. As for preventive measures carried out where possible and still their awareness to obey the law. While repressive action is action taken if preventive measures are not effective, so that the people carrying out the law though involuntarily. While the police in law enforcement there are (two) action that is persuasive and repressive action which has its own purpose. In a persuasive action the police take preventive where often do counseling, provide guidance to the public about the dangers of alcohol. And invite various parties such as $R T, R W$, community leaders participated part in helping oversee the circulation of alcohol in the region. In this case it joined the PP municipal police as well as to both maintain security and order in the region. While the crackdown police investigations, searches, and arrests if there are indications of alcohol trafficking a criminal offense. In this repressive action of the police was a bit of difficulties because traders often rebelled and blocked. In his work the police do alcohol every 1 week operation two to three times, even if there is a report from the police station, police station and the community could have been more. as well as the arrest of a criminal offense if there are indications of alcohol circulation. In this repressive action of the police was a bit of difficulties because traders often rebelled and blocked. In his work the police do alcohol every 1 week operation two to three times, even if there is a report from the police station, police station and the community could have been more. as well as the arrest of a criminal offense if there are indications of alcohol circulation. In this repressive action of the police was a bit of difficulties because traders often rebelled and blocked. In his work the police do alcohol every 1 week operation two to three times, even if there is a report from the police station, police station and the community could have been more. 
- Constraints faced by the Sabhara Kudus Police Unit With regard to the limited number of Members of the Sabhara Kudus Police Unit at the sanctuary that is generally still not satisfactory, not maximum, and uneven steps socialization PERDA conducted at the societal level, so far not infrequent their lack of understanding of exactly related to procedures or systems at the time of preparation until the determination of the law. The problem faced by the police can be seen from internal and external factors which are derived from the organization's internal police while externally originated from outside the organization is society

- Effort or attempt Sabhara Kudus Police Unit in minimizing the violation is by way of non-judicial and pro justicia. Where the non-judicial action is accomplished by providing guidance, exhort or guide in order not to repeat the mistakes that have been made that violates local laws. If this action is less provide a deterrent effect and the parties related to underestimate, then the action pro justicia, tindan pro justicia is taken when actions coaching or non judicial considered insufficient because only given guidance only, then Sabhara Kudus Police Unit may soon crack down and will be brought to trial and be subjected to probation.

\subsection{Suggestion}

- The need to revise regulations that are running so that the regulation will be the legal basis for an effective and makes communities committing a crime deterrent to alcohol circulation.

- The police should conduct raids spontaneously in order to leak information about the implementation of the raid is not spread out in the community so that the parties rogue who committed the crime of trafficking alcohol can not destroy evidence.

- To revise the regulation on alcoholic beverages in Kudus, especially against the sanctions that exist in the area of the rules for the implementation on the ground is still much to repeat the circulation of alcoholic drinks, despite being given a fine and a suspended sentence.

\section{Bibliography}

[1] Hartati, Nurwijaya, 2009, Bahaya Alkohol dan Cara Mencegah Kecanduannya. PT. Elex Media Kompitindo. Jakarta.

[2] Soerjono Soekanto, 1990, Sosiologi Suatu Pengantar, PT. Raja Grafindo Persada, Jakarta

[3] http://finance.detik.com/read/2015/01/28/202639/2817027/4/ini-rincian-aturanlarangan-bir-sold-in-minimarket Accessed on 23 Septeember 2018 At 16:49 pm

[4] Soerdjono Soekanto,1993, Penegakan Hukum, Binacipta. 